\title{
Comparative Analysis of Soil Bacteria Assemblages Across Land-Use Types in a Given Karst Landscape in Southwest China
}

\author{
Qiang Li1 ${ }^{1,2 *}$, Hui Yang ${ }^{1,2}$, Ang Song ${ }^{1,2}$ \\ ${ }^{1}$ Key Laboratory of Karst Dynamics, MNR \& GZAR, Institute of Karst Geology, \\ Chinese Academy of Geological Sciences, Guilin 541004, China \\ ${ }^{2}$ International Research Center on Karst under the Auspices of UNESCO, Guilin 541004, China
}

Received: 2 October 2020

Accepted: 19 November 2020

\begin{abstract}
Land-use types have significant effects on soil microbial communities, yet few studies have compared soil bacteria assemblages in a given karst landscape with multiple land-uses. Consequently, soil samples from cornfields, grasslands, 10 year Eucalyptus forests and undisturbed rock covered soil were collected in triplicate from a given karst area in Southwest China to assess soil bacteria assemblages across land-use types using high-throughput sequencing of the V4-V5 region of the 16S ribosomal RNA gene coupled with soil chemical properties analysis. Our results indicated that soil organic carbon, total nitrogen, total phosphorus, and the exchangeable bases calcium and magnesium were all high in undisturbed rock covered soil and low in cornfields. Though the soil bacterial communities were different in the four land-use types, Acidobacteria, Proteobacteria, Chloroflexi, Actinobacteria, Firmicutes, Verrucomicrobia and Bacteroidetes dominated the soil bacteria communities across all of the soil samples. The soil properties had strong negative or positive correlations with the dominant bacterial phyla with land-use types. And, the gene groups of metabolism, genetic information processing, and environmental information processing with contrasting changes were dominating in grasslands, 10 year Eucalyptus forests and undisturbed rock covered soil. In particular, land-use type exerted significant direct effects on the soil bacterial composition and alpha diversity. Taken together, our findings revealed that land-use types affected soil bacteria assemblages across a given karst landscape in Southwest China.
\end{abstract}

Keywords: karst soil, vegetation change, rocky desertification, high-throughput 16S ribosomal RNA gene amplicon sequencing, bacterial community structure

*e-mail: glqiangli@hotmail.com 


\section{Introduction}

In the karst area of Southwest China, arable lands are limited. As a result of the increasing demand for food crops, natural lands (rock covered soils) are being converted to cropland at an alarming rate [1]. Due to specific geological and hydrological background, and underground structure in the karst zone, the croplands at these sites are susceptible to soil erosion, resulting in karst rocky desertification (KRD) that is nearly devoid of vegetation and soil [1]. To overcome KRD in Southwest China, a project aimed at converting degraded farm land into forest and grassland was carried out by the Chinese government [1]. Consequently, the croplands or KRD areas were converted to man-made forests (especially fast-growing Eucalyptus trees) or grasslands to improve the karst ecological environment, which usually had been under natural restoration without human intervention [2]. Subsequently, the soil physical and chemical properties were changed relevantly accompanied by the above mentioned transformation (land-use change) [3].

Land-use changes had significant influences on soil microorganisms, which play central roles in soils [4]. Then, He et al. [5] found that karst soil bacterial communities that were most sensitive to land-use types were those associated with tussocks, followed by shrubs, secondary forests and primary forests in Guangxi, China. Under the advent of high-throughput sequencing technologies, Liao et al. [6] found that the relative abundances of Actinobacteria were greatly increased from cropland to orchards as a result of the impact of land-use conversion in a degraded karst ecosystem. However, there is still a gap in karst microbial ecology research [7] because less attention has been paid to original soil developed from limestone, namely, undisturbed rock covered soil [8]. To better understand karst soil bacteria assemblages with contrasting land-use changes, three questions will be addressed in our study: (i) Do karst soil bacterial communities change substantially with land-use type? (ii) Which factor is most important in shaping soil bacterial community compositions? and (iii) Can soil bacterial community compositions be predicted based on landuse changes?

In this respect, the 'space-for-time substitution' approach as a surrogate was applied [9], though it had some methodological shortcomings. It is often considered as the only way of determining the influence of land-use changes on soil microorganisms [9]. Thus, a set of soil samples from corn fields (C), grasslands (G), 10 year Eucalyptus forests (E) and undisturbed rock covered soil $(\mathrm{R})$ were collected in October, 2016 to compare soil bacteria assemblages across land-use types in a given karst landscape in Southwest China using high-throughput sequencing of the V4-V5 region of the $16 \mathrm{~S}$ ribosomal RNA gene. Moreover, the large $16 \mathrm{~S}$ ribosomal RNA datasets coupled with soil chemical properties can improve our understanding of how shifts in the abundance and composition of these bacterial communities.

\section{Materials and Methodology}

\section{Sample Location}

Soil samples were from the Hani-Yi Autonomous Prefecture of Honghe, Yunan Province, China (101 $47^{\prime}-$ $\left.104^{\circ} 16^{\prime} \mathrm{E}, 22^{\circ} 26^{\prime}-24^{\circ} 45^{\prime} \mathrm{N}\right)$. In this study area, the soils formed from limestone bedrock are usually $20-40 \mathrm{~cm}$ thick. Based on the fact that Yunnan Plateau has a significant influence on atmospheric circulation due to its mechanical and thermodynamic effects, approximately $80 \%$ of the annual rainfall amount occurs in the rainy season between May and October at this area [10]. The average annual rainfall is $2026.5 \mathrm{~mm}$ and the average annual temperature is $16.3^{\circ} \mathrm{C}$ [11]. In this respect, this area falls within the subtropics with two distinctive seasons (dry season from Nov. to Apr. and wet season from May to Oct.).

\section{Soil Sampling}

Twelve plots of approximately $10 \times 10 \mathrm{~m}$ in size were selected for soil sampling in October, 2016. There were four land-use types in the twelve total plots in our study. The corn fields are used for planting maize (Zea mays) continuing for 10 years with fertilizer application (264:75:13.5 $\left.\mathrm{kg} \quad \mathrm{N}: \mathrm{P}_{2} \mathrm{O}_{5}: \mathrm{K}_{2} \mathrm{O} / \mathrm{hm}^{2}\right)$, the grassland with no grazing from abandoned cornfields about eight years ago is mainly covered by Arundinella setosa, the 10 year Eucalyptus forests are covered mainly by Eucalyptus robusta Smith after agricultural abandonment, and the undisturbed rock covered soil is covered mainly by Bauhinia brachycarpa, Cymbopogon distans and Cyclobalanopsis glaucoides Schotky. Moreover, the grasslands and 10 year Eucalyptus forests had been under natural restoration without human intervention at this area. At each land-use type, three near plots were distributed along S-type. Moreover, three cores of $5 \mathrm{~cm}$ in diameter and $10 \mathrm{~cm}$ in depth were randomly selected and combined to obtain a composite soil sample for each plot. After stones, plants and root debris were removed, twelve soil samples were used for future analysis.

\section{Analysis of Soil Chemical Properties}

The air-dried and sieved $(0.2 \mathrm{~mm})$ soil samples were used to analyze $\mathrm{pH}$, soil organic carbon (SOC), total nitrogen (TN) and total phosphorus (TP) according to Li et al. $[12,13]$. The exchangeable bases calcium (E-Ca) and magnesium (E-Mg) were extracted using an ionexchange resin [14]. The soil chemical properties are summarized in Table 1. 
Table 1. Mean soil properties for each land-use type.

\begin{tabular}{|c|c|c|c|c|c|c|}
\hline \multirow{2}{*}{$\begin{array}{c}\text { Sample } \\
\text { type }\end{array}$} & $\mathrm{pH}$ & $\mathrm{SOC}$ & $\mathrm{TN}$ & $\mathrm{E}-\mathrm{Ca}$ & $\mathrm{E}-\mathrm{Mg}$ & $\mathrm{TP}$ \\
\cline { 2 - 7 } & & $\mathrm{g} / \mathrm{kg}$ & $\mathrm{g} / \mathrm{kg}$ & $\mathrm{mg} / \mathrm{g}$ & $\mathrm{mg} / \mathrm{g}$ & $\mathrm{mg} / \mathrm{g}$ \\
\hline $\mathrm{C}(\mathrm{n}=3)$ & $5.93 \pm 0.33 \mathrm{~b}$ & $16.27 \pm 4.39 \mathrm{~b}$ & $0.57 \pm 0.12 \mathrm{~b}$ & $2.72 \pm 0.66 \mathrm{~b}$ & $3.46 \pm 0.30 \mathrm{~b}$ & $0.94 \pm 0.05 \mathrm{ab}$ \\
\hline $\mathrm{G}(\mathrm{n}=3)$ & $6.73 \pm 0.09 \mathrm{ab}$ & $22.88 \pm 2.76 \mathrm{ab}$ & $0.74 \pm 0.08 \mathrm{ab}$ & $3.65 \pm 0.48 \mathrm{ab}$ & $3.74 \pm 0.11 \mathrm{~b}$ & $0.85 \pm 0.10 \mathrm{~b}$ \\
\hline $\mathrm{E}(\mathrm{n}=3)$ & $6.18 \pm 0.27 \mathrm{~b}$ & $26.08 \pm 1.99 \mathrm{ab}$ & $0.80 \pm 0.10 \mathrm{ab}$ & $4.10 \pm 0.70 \mathrm{ab}$ & $4.63 \pm 0.11 \mathrm{a}$ & $0.97 \pm 0.03 \mathrm{ab}$ \\
\hline $\mathrm{R}(\mathrm{n}=3)$ & $7.11 \pm 0.08 \mathrm{a}$ & $34.64 \pm 4.76 \mathrm{a}$ & $1.17 \pm 0.21 \mathrm{a}$ & $5.16 \pm 0.90 \mathrm{a}$ & $4.42 \pm 0.13 \mathrm{a}$ & $1.15 \pm 0.10 \mathrm{a}$ \\
\hline
\end{tabular}

Values are the means of three analytical replicates for each sample \pm standard deviations. Statistical pairwise multiple comparisons of data homogeneity were carried out by the Tukey test; means with the same letter in the same column are not significantly different at $P<0.05$.

\section{High-Throughput Sequencing and Bioinformatic Analysis}

Soil DNA was extracted using the Powersoil ${ }^{\circledR}$ DNA Isolation Kit (Mobio Laboratories, Inc., Carlsbad, CA, USA) in strict accordance with the manufacturer's instructions. After DNA extraction, universal primers $515 \mathrm{~F}$ and $907 \mathrm{R}$ were used for amplification of the V4-V5 region of the 16S ribosomal RNA genes [15]. The PCR products targeting the V4-V5 region of the 16S ribosomal RNA genes were purified using the TIANquick Maxi Purification Kit (TIANGEN Biotech (Beijing) Co., Ltd, China). Subsequently, 16S ribosomal RNA gene sequencing was performed on the Illumina HiSeq 2500 platform (Illumina Inc., San Diego, CA, USA) by the MAGIENE company (Guangzhou, China).

The 16S sequencing data obtained from the twelve soil samples were submitted to the NCBI Sequence Read Archive under the accession number SRP145453 and processed using the QIIME 1.7.0 software [16]. In our article, fast length adjustment of short reads software was used to merge and extend the paired-end Illumina reads using the default parameters, with a maximum overlap of $400 \mathrm{bp}$ [17]. Low-quality sequences with lengths shorter than $150 \mathrm{bp}$ or an average quality score below 30 were excluded, and chimeric sequence reads were also removed. In addition, sequences matching plant chloroplast or mitochondrial $16 \mathrm{~S}$ ribosomal RNA were filtered out. Representative sequences from each OTU clustered at $97 \%$ similarity level were aligned to the SILVA128 ribosomal RNA databases by using PyNAST. Consequently, 946021 low-quality reads generated 317017 high-quality reads grouped into 138380 OTUs. The coverage ranged from $98.12 \%$ to $98.48 \%$. Bootstrap OTU richness, Chao 1 estimates, the inverse Simpson index (i.e., a measure of evenness) and the Simpson diversity index, as well as the Fisher index were calculated on rarefied OTU tables to assess the distribution patterns of the OTUs of the soil bacterial communities (three analytical replicates for each landuse type).

\section{Data Analysis}

By referring to the analysis of Ávila et al. [18] to assess the similarity in OTU structure among the different soil bacterial communities, the unweighted UniFrac and Bray-Curtis distances were visualized by using principal coordinate analysis (PCoA) plots generated with the EMPeror software package [19]. The R ggplot2 package was applied for linear regression analysis to explore the relationships between the bacteria at phylum level and the soil properties [20]. Heat maps were generated using $\mathrm{R}$ software to illustrate the relative frequencies of soil bacteria. Spearman correlation analyses were used to explore the relationships between the bacteria at phylum level and the alpha-diversity indices with soil properties, and the Tukey test was used to reveal significant differences among soil properties and diversity indices with SPSS 13.0 software for Windows XP (IBM, Armonk, NY, USA). Redundancy analysis (RDA) was used to detect the strength of soil chemical factors upon soil bacterial community structures and OTU associations with samples. Correlation networks were used to detect the interactions among the most abundant OTUs and between these OTUs and the soil chemical variables [18]. Their interactions with $P$ values $<0.05$ based on Pearson's product-moment correlation were visualized and customized using Gephi 0.9.2 [21]. For functional predictions, functional inferences within the Kyoto Encyclopedia of Genes and Genomes (KEGG) ontology were made using PICRUSt (phylogenetic investigation of communities by reconstruction of unobserved states) software [22]. It should be noted that land use can affect soil organic matter contents and $\mathrm{pH}$, where calcium and magnesium allocating carbon will ultimately determine these processes [23]. To explore the correlations among soil bacterial communities (the most abundant OTUs), land-use ( $\mathrm{pH}, \mathrm{E}-\mathrm{Ca}$ and $\mathrm{E}-\mathrm{Mg}$ ) and nutrition (SOC, $\mathrm{TN}$ and TP), and to eliminate collinearity between the variables, the partial Mantel test was carried out using PASSaGE 2 [24]. Moreover, the partial least squares path model (PLS-PM) was constructed with $\mathrm{R}$ using the plspm, boot and vegan packages [24] to explore 
the relationships among the soil bacterial communities, the alpha diversity, land-use and nutrition factors. These data were represented here with a goodness-of-fit (GoF) value of 0.66 to integrate the complex interrelationships among the soil chemical properties and the bacterial communities. Analysis of similarity (ANOSIM) tests were conducted using the $\mathrm{R}$ vegan package to determine the statistical differences between groups of soil samples by permutation of group membership with 999 replicates. The test statistic $\mathrm{R}$, which measures the strength of the results, ranges from -1 to $1(\mathrm{R}=1$ signifies differences between groups, while $R=0$ signifies that the groups are identical).

\section{Results}

\section{Karst Soil Chemical Characteristics}

The soil properties of the four different landuse soils are listed in Table 1. Soil $\mathrm{pH}, \mathrm{SOC}, \mathrm{TN}, \mathrm{TP}$, $\mathrm{E}-\mathrm{Ca}$ and $\mathrm{E}-\mathrm{Mg}$ were lower in $\mathrm{C}$ soils than those in the other soils (E, G and R), although such differences may not be significant. As a whole the soil $\mathrm{pH}, \mathrm{SOC}$, $\mathrm{TN}, \mathrm{TP}, \mathrm{E}-\mathrm{Ca}$ and $\mathrm{E}-\mathrm{Mg}$ have increased with positive succession. In addition, the soil chemical properties (except $\mathrm{pH}$ ) of the E soils were similar to those of the $\mathrm{G}$ soils. Interestingly, soil $\mathrm{pH}, \mathrm{SOC}, \mathrm{TN}, \mathrm{TP}, \mathrm{E}-\mathrm{Ca}$ and $\mathrm{E}-\mathrm{Mg}$ were all high in the $\mathrm{R}$ soils, while they were low in the $\mathrm{C}$ soils. It should be noted, however, that all soil chemical attributes except TP differed significantly in the $\mathrm{R}$ and $\mathrm{C}$ soils. In addition, SOC, TN and E-Ca concentrations in the $\mathrm{R}$ soils were approximately twice times higher than those in the $\mathrm{C}$ soils.

\section{Karst Soil Bacterial Community Composition}

Of the 317017 filtered reads, 95.55\% (Archaea excluded) were assigned to 10 phyla, with the remainder being un-assigned to a known bacterial phylum. Acidobacteria, Proteobacteria, Chloroflexi, Actinobacteria, Firmicutes, Verrucomicrobia and Bacteroidetes (mean relative abundance $>5 \%$; Fig. 1) dominated the soil bacteria communities across all of the soil samples. Moreover, according to the linear relationship between the dominant bacterial phyla and $\mathrm{pH}$, the relative abundance of Acidobacteria (y $\left.=0.13 \mathrm{pH}-0.61, R^{2}=0.74, p<0.01\right)$, Chloroflexi $\left(\mathrm{y}=0.05 \mathrm{pH}-0.24, R^{2}=0.75, p<0.01\right)$, and Bacteroidetes $\left(\mathrm{y}=0.01 \mathrm{pH}+0.02, R^{2}=0.05, p=0.5\right)$ increased from $\mathrm{C}$ soils, to $\mathrm{E}$ soils, to $\mathrm{G}$ soils, to $\mathrm{R}$ soils, while the abundance of Proteobacteria $(\mathrm{y}=-0.13 \mathrm{pH}+1.08$, $\left.R^{2}=0.67, p<0.01\right)$, Firmicutes $(\mathrm{y}=-0.07 \mathrm{pH}+0.55$, $\left.R^{2}=0.51, p<0.01\right)$ and Actinobacteria $(\mathrm{y}=-0.01 \mathrm{pH}$ $+0.16, R^{2}=0.02, p=0.7$ ) displayed the opposite pattern. However, Bacteroidetes, Actinobacteria and $\mathrm{pH}$ did not show significant correlations $(p>0.05)$. In addition, the number of observed OTUs (at the $97 \%$ similarity level) ranged from 1125 to 1300 across the twelve soils (Table 2). 21 dominant bacterial OTUs (relative abundance $>0.5 \%$ ) were highly abundant in the twelve soils. Among them, half of the OTUs were classified into Proteobacteria and Acidobacteria. Chloroflexi spp., Bacteroidetes spp. and Verrucomicrobia spp. were also frequently observed. A heat map was used to illustrate the associations among the most abundant OTUs and their niches (Fig. 2a). Of the dominant OTUs, Acidobacteria-related OTU 5 (y $=1898$ pH - 10161, $\left.R^{2}=0.69, p<0.01\right)$, Acidobacteria-related OTU 13 $\left(\mathrm{y}=314.8 \mathrm{pH}-1676, R^{2}=0.73, p<0.01\right)$ and Chloroflexirelated OTU $18\left(\mathrm{y}=500.6 \mathrm{pH}-267, R^{2}=0.58, p<0.01\right)$ were increased with $\mathrm{pH}$. By contrast, Firmicutes-related OTU 1 (y $\left.=-1553 \mathrm{pH}+12036, R^{2}=0.52, p<0.01\right)$, Proteobacteria-related OTU 2 (y $=-1284 \mathrm{pH}+9775$, $\left.R^{2}=0.58, p<0.01\right)$ and Proteobacteria-related OTU 3 $\left(\mathrm{y}=-592.1 \mathrm{pH}+4507, R^{2}=0.67, p<0.01\right)$ were decreased with $\mathrm{pH}$. Notably, other soil properties did not showed statistically significant results with soil bacteria.

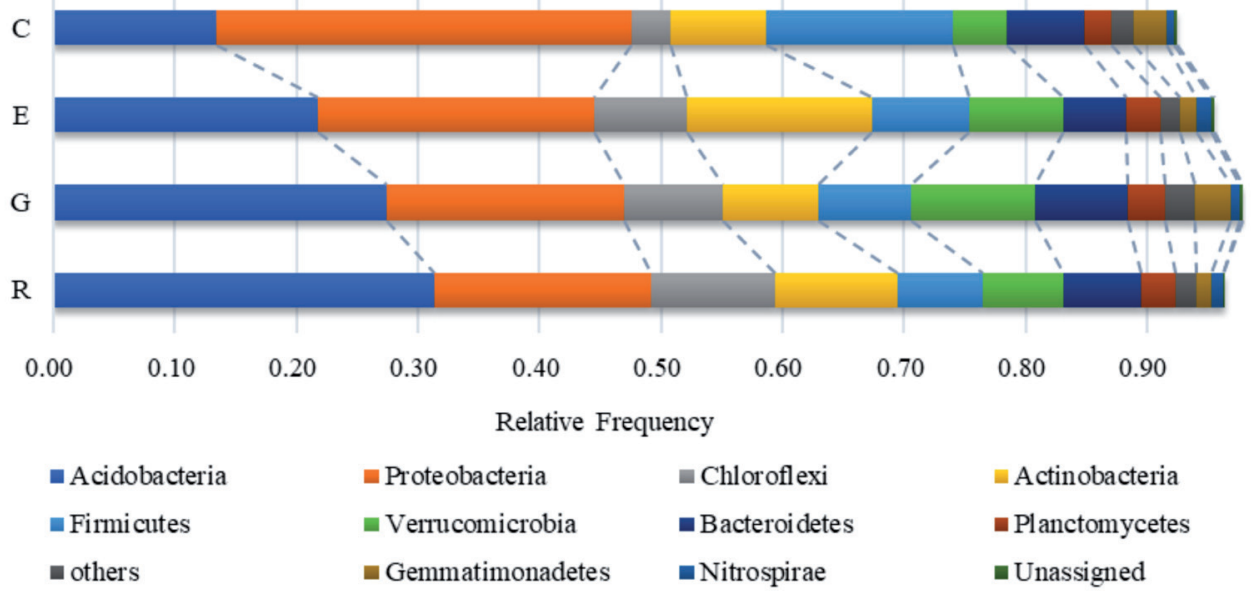

Fig. 1. Taxonomic distribution based on the V4-V5 16S rRNA tags from the bacterial communities in the four land-use types. Phyla with a relative abundance $<1 \%$ in all soil samples were grouped as "Other phyla". 
Table 2. Mean alpha-diversity of each land-use type

\begin{tabular}{|c|c|c|c|c|c|c|}
\hline Sample type & Chao1 & Shannon & Simpson & Observed OTUs & $\begin{array}{c}\text { Goods coverage } \\
(\%)\end{array}$ & Fisher's alpha \\
\hline C (n=3) & $1492 \pm 107 \mathrm{a}$ & $6.46 \pm 0.35 \mathrm{~b}$ & $0.94 \pm 0.02 \mathrm{~b}$ & $1125 \pm 81 \mathrm{~b}$ & $98.36 \pm 0.11 \mathrm{a}$ & $250.84 \pm 23.12 \mathrm{~b}$ \\
\hline $\mathrm{G}(\mathrm{n}=3)$ & $1607 \pm 56 \mathrm{a}$ & $6.97 \pm 0.05 \mathrm{ab}$ & $0.96 \pm 0.00 \mathrm{ab}$ & $1265 \pm 28 \mathrm{ab}$ & $98.27 \pm 0.07 \mathrm{a}$ & $291.12 \pm 8.38 \mathrm{ab}$ \\
\hline $\mathrm{E}(\mathrm{n}=3)$ & $1590 \pm 4 \mathrm{a}$ & $7.36 \pm 0.21 \mathrm{a}$ & $0.97 \pm 0.00 \mathrm{a}$ & $1281 \pm 34 \mathrm{ab}$ & $98.37 \pm 0.04 \mathrm{a}$ & $295.82 \pm 10.05 \mathrm{ab}$ \\
\hline $\mathrm{R}(\mathrm{n}=3)$ & $1652 \pm 48 \mathrm{a}$ & $7.13 \pm 0.17 \mathrm{ab}$ & $0.96 \pm 0.01 \mathrm{ab}$ & $1300 \pm 40 \mathrm{a}$ & $98.25 \pm 0.06 \mathrm{a}$ & $301.56 \pm 11.99 \mathrm{a}$ \\
\hline
\end{tabular}

Values are the means of three analytical replicates for each sample \pm standard deviations. Statistical pairwise multiple comparisons of data homogeneity were carried out by the Tukey test; means with the same letter in the same column are not significantly different at $P<0.05$.

a)

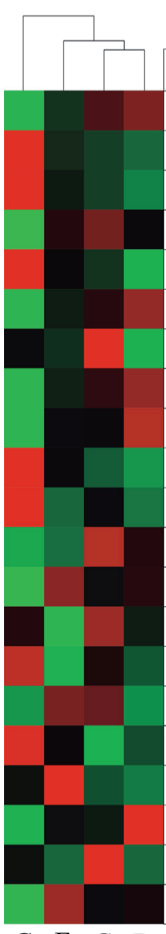

c) b)

\begin{tabular}{|c|c|}
\hline OTU & Taxonomy \\
\hline OTU5 & Acidobacteria RB41 \\
\hline OTU1 & Bacillaceae \\
\hline OTU2 & Enterobacteriaceae \\
\hline OTU6 & DA101 soil group1 \\
\hline OTU3 & Moraxellaceae \\
\hline OTU18 & Anaerolineaceael \\
\hline OTU9 & DA101 soil group2 \\
\hline OTU13 & Acidobacteria_Sub1 \\
\hline OTU15 & Anaerolineaceae2 \\
\hline OTU7 & Pseudomonadaceae \\
\hline OTU17 & Sphingomonadaceae \\
\hline OTU12 & Chitinophagaceae I \\
\hline OTU72 & Acidobacteria_Sub2 \\
\hline OTU22 & Chitinophagaceae2 \\
\hline OTU34 & Nitrosomonadaceae \\
\hline OTU19 & Micromonosporaceae \\
\hline OTU10 & Burkholderiaceae \\
\hline OTU16 & Bradyrhizobiaceae \\
\hline OTU31 & Anaerolineaceae3 \\
\hline OTU11 & Gemmatimonadaceae \\
\hline OTU48 & Acidobacteria_Sub3 \\
\hline
\end{tabular}
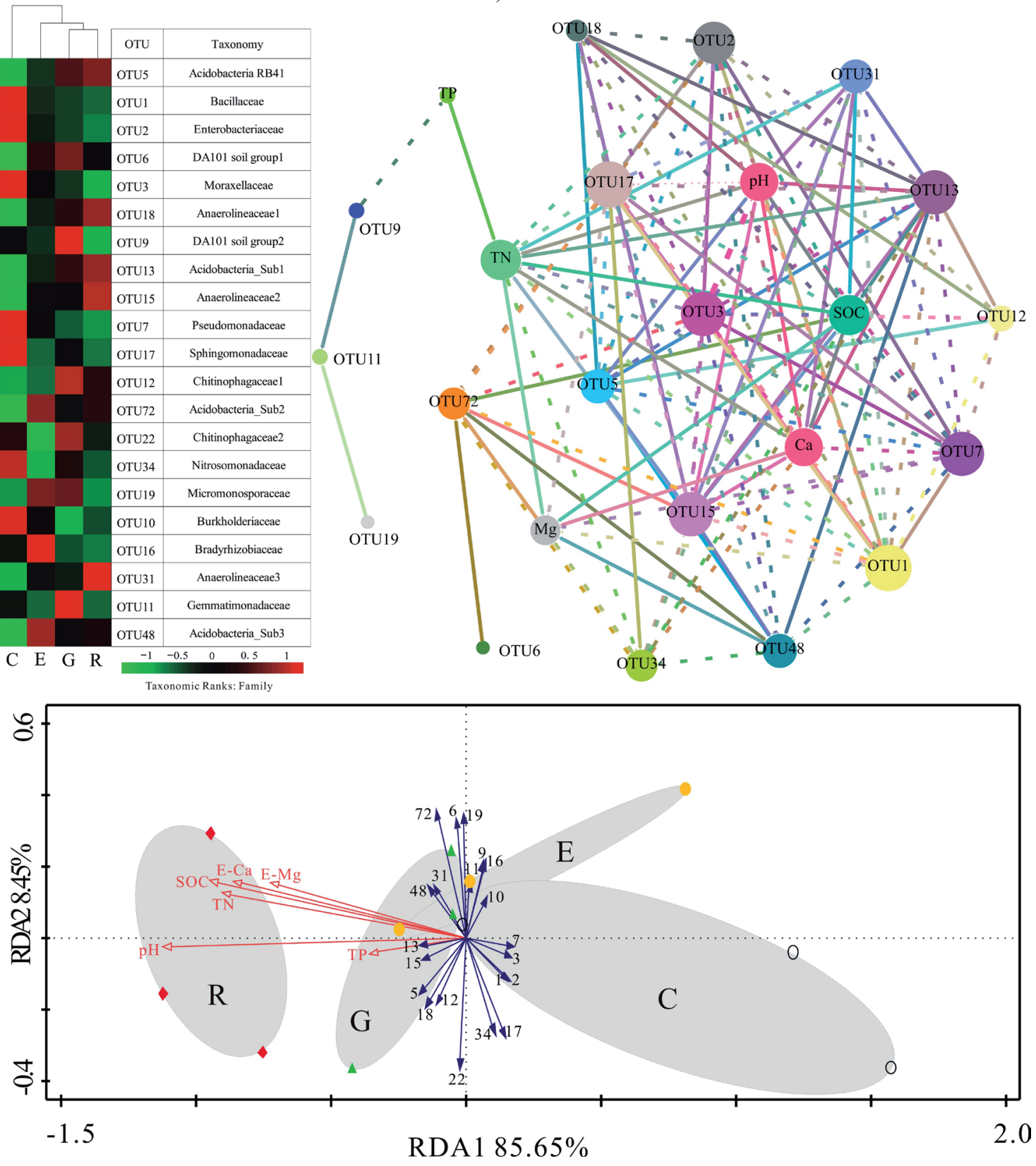

Fig. 2 a) Heat map illustrating the 21 most abundant OTUs in the four land-use types. b) Correlation network illustrating the positive (solid lines) and negative (dashed lines) correlations among OTUs (node color corresponds to taxonomic affiliation) as well as the correlations between OTUs and soil properties. Node size is proportional to the OTU abundance. (C) RDA plot reflecting the relationships between the top 21 OTUs and the soil properties. $\bullet$ indicting the R soil, $\mathbf{\Delta}$ indicting the G soil, $\bigcirc$ indicting the E soil, and oindicting the C soil. 
Table 3. Spearman's correlations between the relative abundance of the different bacterial phyla, the alpha-diversity of bacteria and soil properties.

\begin{tabular}{|c|c|c|c|c|c|c|c|c|c|c|c|c|}
\hline & \multicolumn{2}{|c|}{$\mathrm{pH}$} & \multicolumn{2}{c|}{ SOC } & \multicolumn{2}{c|}{ TN } & \multicolumn{2}{c|}{ E-Ca } & \multicolumn{2}{c|}{ E-Mg } & \multicolumn{2}{c|}{ TP } \\
\cline { 2 - 12 } & $\mathrm{r}$ & $\mathrm{p}$ & $\mathrm{r}$ & $\mathrm{p}$ & $\mathrm{r}$ & $\mathrm{p}$ & $\mathrm{r}$ & $\mathrm{p}$ & $\mathrm{r}$ & $\mathrm{p}$ & $\mathrm{r}$ & $\mathrm{p}$ \\
\hline Acidobacteria & $0.727^{* *}$ & 0.007 & $0.657^{*}$ & 0.020 & $0.664^{*}$ & 0.018 & & & & & \\
\hline Actinobacteria & & & & & & & & & $0.622^{*}$ & 0.031 & \\
\hline Chloroflexi & $0.797^{* *}$ & 0.002 & $0.769^{* *}$ & 0.003 & $0.762^{* *}$ & 0.004 & $0.601^{*}$ & 0.039 & & & \\
\hline Firmicutes & & & $-0.657^{*}$ & 0.020 & $-0.664^{*}$ & 0.018 & $-0.587^{*}$ & 0.045 & & & & \\
\hline Gemmatimonadetes & & & $-0.622^{*}$ & 0.031 & & & & & & & \multirow{2}{*}{$-0.704^{*}$} & 0.011 \\
\hline Nitrospirae & & & & & & & & & $0.860^{* *}$ & 0.000 & & \\
\hline Proteobacteria & $-0.657^{*}$ & 0.020 & $-0.601^{*}$ & 0.039 & $-0.636^{*}$ & 0.026 & & & & & & \\
\hline Chao1 & $0.594^{*}$ & 0.042 & $0.601^{*}$ & 0.039 & $0.629^{*}$ & 0.028 & & & & & & \\
\hline Shannon & & & $0.664^{*}$ & 0.018 & $0.601^{*}$ & 0.039 & $0.671^{*}$ & 0.017 & $0.713^{* *}$ & 0.009 & & \\
\hline Simpson & & & & & & & & & $0.706^{*}$ & 0.010 & & \\
\hline Observed OTUs & $0.671^{*}$ & 0.017 & $0.755^{* *}$ & 0.005 & $0.741^{* *}$ & 0.006 & $0.608^{*}$ & 0.036 & & & & \\
\hline Fisher index & $0.671^{*}$ & 0.017 & $0.755^{* *}$ & 0.005 & $0.741^{* *}$ & 0.006 & $0.608^{*}$ & 0.036 & & & & \\
\hline
\end{tabular}

$* p$ values at the 0.05 level (Two-tailed), $* * p$ values at the 0.01 level (Two-tailed).

The correlation between soil properties and some bacteria OTUs was demonstrated in Table 3 and Fig. 2b). Soil properties had significantly positive or negative relationships with the dominant bacterial phyla including Acidobacteria, Actinobacteria, Chloroflexi, Firmicutes, Gemmatimonadetes, Nitrospirae and Proteobacteria (Table 3), which were also confirmed by the linear relationships between them and $\mathrm{pH}$ as mentioned above. Moreover, the network analysis demonstrated that soil properties were strongly correlated with different OTU clusters, regardless of whether their relationship was negative or positive, as seen in Fig. 2b).

Additionally, RDA was carried out to better explore which soil properties had the greatest influence on bacterial community structures (Fig. 2c). The RDA result revealed that the OTU distribution across all soil samples in the given karst landscapes could be mainly explained by the RDA1 axis, which was significantly correlated only with $\mathrm{pH}$ (pseudo-F $=12.6, P=0.024$ ) and explained $55.7 \%$ of the influence of soil properties (Pseudo-F more than 1 indicates that they are effectively different).

\section{Karst Soil Bacterial Diversity with Land Use Changes}

Based on the number of observed OTUs in each type of land-use karst soil, the Chaol estimate ranged from 1492 to 1652 OTUs, and the coverage ranged from $98.25 \%$ to $98.37 \%$ (Table 2), suggesting that the achieved sequencing depth was sufficient for our study. In addition, the Fisher index, Shannon diversity and Simpson indices were 250.84-301.56, 6.46-7.36 and 0.94-0.97, respectively, in the sampled soils. The results also revealed that the observed OTUs and the Fisher index were significantly higher in the $\mathrm{R}$ soils than those in $\mathrm{C}$ the soils. The general difference in the beta diversity visualized by PCoA tool with Bray-Curtis and unweighted UniFrac distance matrices are shown in Fig. 3. Each soil sample had a different and native bacterial community. As in the case of the Bray-Curtis distance, pronounced influence of land-use types on the karst soil bacterial community structure was found, which was consistent with the results in Fig. 2c). The results of the unweighted UniFrac distance matrix also revealed the dissimilarity among the karst soil bacterial communities. Moreover, ANOSIM further revealed that land-use types exerted a strong influence on the soil bacteria community structure without significant statistical differences, as seen in Fig. 4.

\section{The Influence of Karst Soil Factors on Bacterial Communities}

As noted above, karst soil physiochemical attributes could affect soil bacterial community composition. However, these factors were not independent. Because soil is an immensely complex system, it is not surprising that we observed the difference of predicted functional genes based on the bacterial OTUs with four land-use types (Fig. 5). The gene groups of metabolism, genetic information processing, environmental information processing, and cellular processes with contrasting changes were dominating in the $\mathrm{E}, \mathrm{G}$ and $\mathrm{R}$ soils. Moreover, to better integrate the influence of land-use 

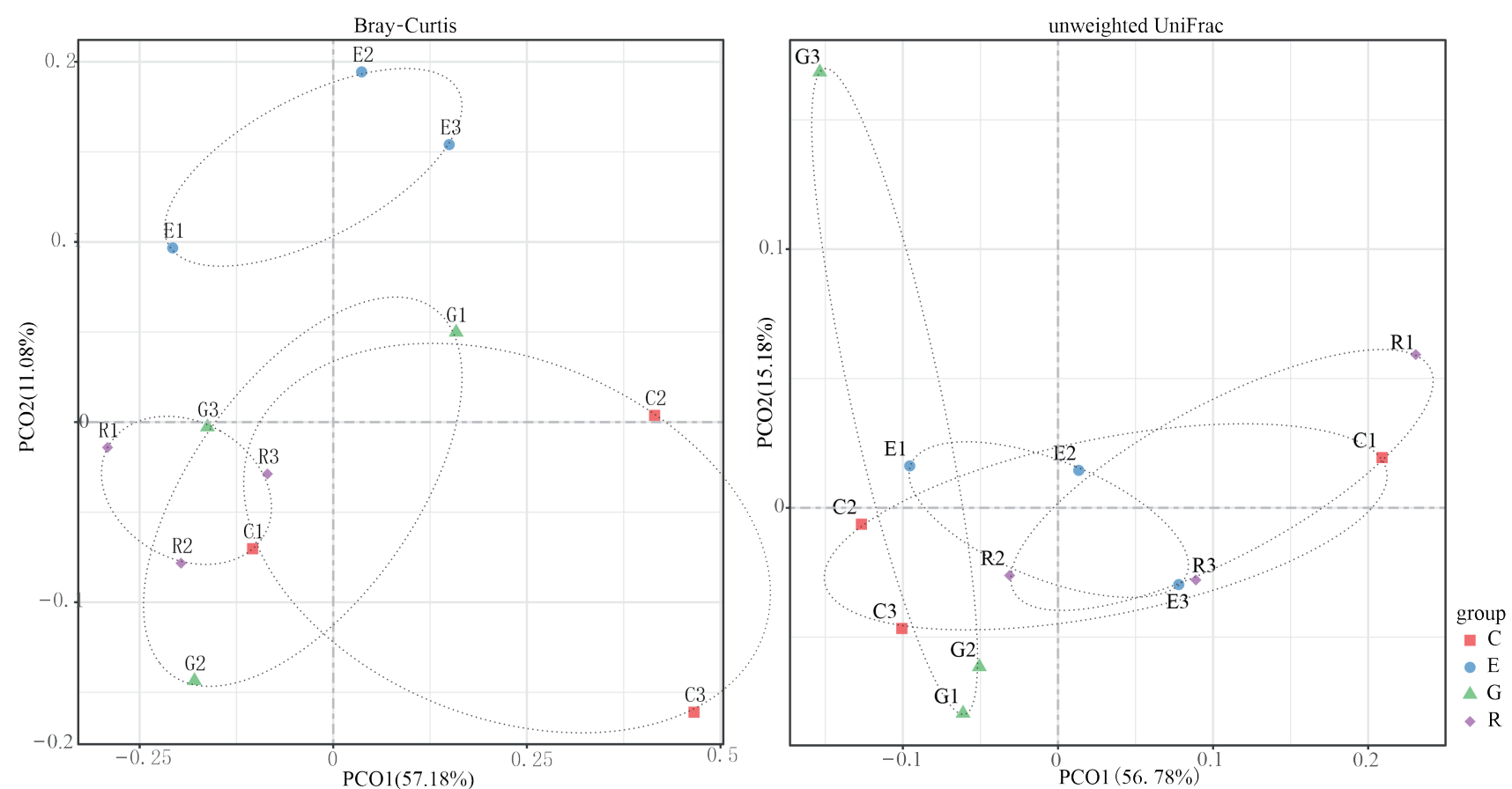

Fig. 3. PCoA plots of soil bacterial community structures based on the unweighted UniFrac and Bray-Curtis results.

on bacterial communities, a PLS-PM was constructed in Fig. 6. Land-use type exerted significant and direct positive effects on nutrition $(r=0.91, p<0.01)$ and alpha diversity $(r=1.15, p<0.05)$; however, it exerted significant and direct negative effect on bacterial composition $(r=-0.532, p<0.05)$. A partial Mantel test also showed that land-use type had a significant effect on the soil bacterial community $(p<0.05)$, and the alpha diversity was significantly correlated with the soil bacterial communities $(p<0.01)$ (Table 4$)$.

\section{Discussion}

Since the parent rock can strongly influence soil chemical properties [25], the soils developed from carbonate rocks in Southwest China are characterized by high concentrations of calcium and magnesium, as well as high $\mathrm{pH}$ values [23]. Calcium and magnesium will combine with the solubilized organic materials (humic acid or fulvic acid) to improve the organic carbon contents without anthropogenic disturbances
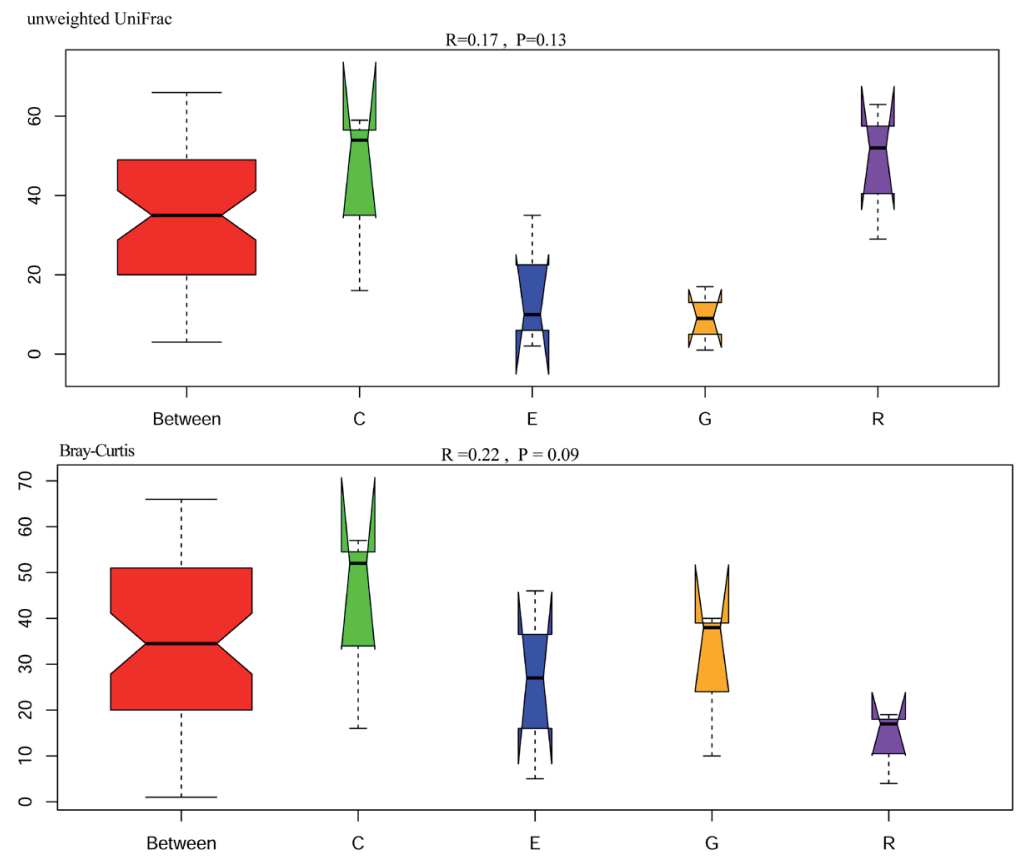

Fig. 4. Analysis of similarity (ANOSIM) for comparison of soil bacterial community composition in the four land-use types. 

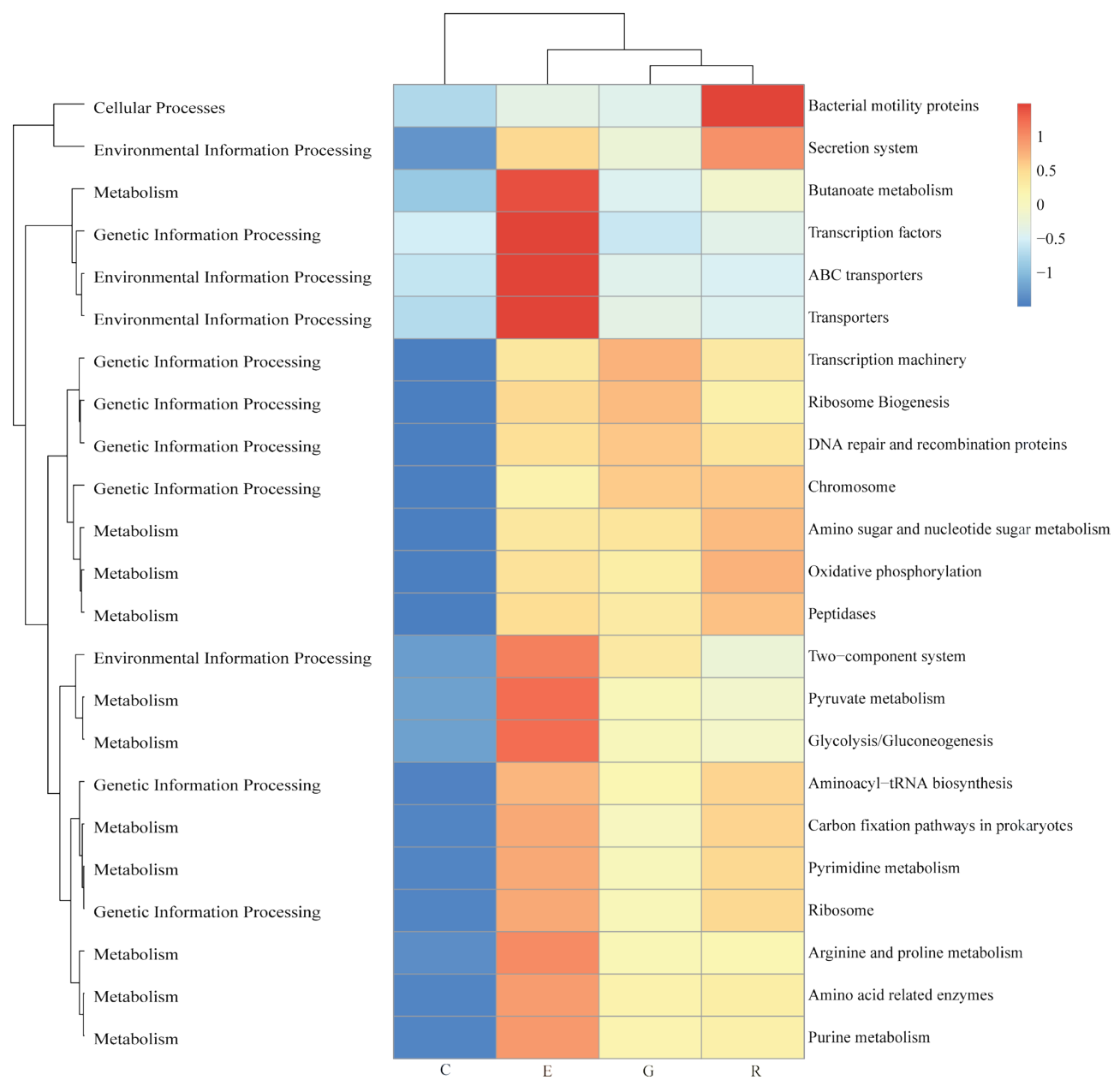

Fig. 5. Heat map illustrating the relative proportion of the functional genes with a relative abundance $>1 \%$ predicted by the PICRUSt software based on the bacterial OTUs in the four land-use types.

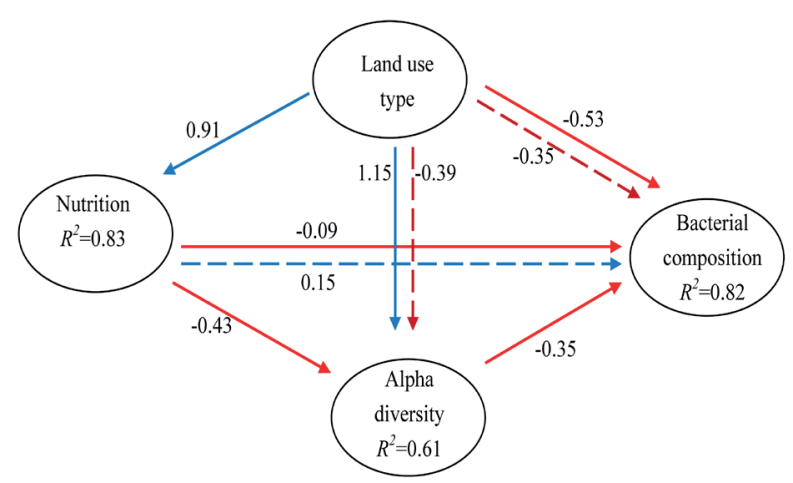

Fig. 6. Directed graph of the PLS-PM of land-use ( $\mathrm{pH}, \mathrm{E}-\mathrm{Ca}$ and $\mathrm{E}-\mathrm{Mg}$ ) and nutrition (SOC, TN and TP) effects on bacterial communities (the 21 most abundant OTUs) and alpha diversity. Note: The path coefficients and the explained variability $\left(R^{2}\right)$ in our study were calculated after 999 bootstraps. Blue solid arrows indicate positive direct effects, red solid arrows indicate negative direct effects, blue dashed arrows indicate positive indirect effects, and red dashed arrows indicate negative indirect effects. Models with different structures were assessed using the Goodness of Fit (GoF) statistic, a measure of the overall prediction performance. For the PLS-PM represented here, the GoF was 0.66 .
[23]. Moreover, $\mathrm{Ca}^{2+}$ and $\mathrm{Mg}^{2+}$ are the predominant exchangeable ions in calcareous soils [26]. Under the influence of anthropogenic causes, the losses of soil $\mathrm{Ca}^{2+}$ and $\mathrm{Mg}^{2+}$ during soil erosion process drove soil acidification accompanied by shifts in vegetation at karst area [27]. Subsequently, the soil $\mathrm{pH}$ progressively increased from the cultivated land, to the forested land, to the grass land, to the construction land (undisturbed rock covered soil), which was similar to the results reported by Jiang et al. [28]. That is to say, the decrease of $\mathrm{pH}$, calcium and magnesium was accompanied by the ecological degradation. Besides that, SOC, TN and TP were all high in the $\mathrm{R}$ soils and low in the $\mathrm{C}$ soils, which was similar to the previous report that contents of soil carbon, nitrogen and phosphorus of no rocky desertification were significantly more than those of potential, slight, and severe degrees of KRD area in Southwest China [29]. Moreover, the absence of $\mathrm{Mg}^{2+}$ stimulates microbial decomposition of litter, leading to an increase of the leaching of soluble minerals [30].

Although the importance of soil properties in shaping microbial communities has been demonstrated by many studies [4, 31], few studies have examined which specific soil properties do, or do not, influence 
Table 4. The influence of soil factors on bacterial communities by the partial Mantel test.

\begin{tabular}{|c|c|c|c|c|c|c|c|c|}
\hline Effect of & \multicolumn{4}{|c|}{ Land use type } & \multicolumn{2}{|c|}{ Nutrition } & & \\
\hline Controlling for & & & \multicolumn{2}{|c|}{ Nutrition } & & & \multicolumn{2}{|c|}{ Land use type } \\
\hline \multirow{2}{*}{$\begin{array}{l}\text { Bacterial com- } \\
\text { position }\end{array}$} & $\mathrm{r}$ & $\mathrm{P}$ & $\mathrm{r}$ & $\mathrm{P}$ & $\mathrm{r}$ & $\mathrm{P}$ & $\mathrm{r}$ & $\mathrm{P}$ \\
\hline & 0.420 & 0.041 & -0.031 & 0.841 & 0.481 & 0.051 & 0.259 & 0.226 \\
\hline
\end{tabular}

Bold indicates a significant correlation $(p<0.05)$.

the composition of soil bacteria within multiple landuse types in a given karst landscape. Previous studies have demonstrated that soil $\mathrm{pH}$ can be a predictor for soil bacterial community composition [7,32]. This is in close accordance with the fact that deviations of $1.5 \mathrm{pH}$ units from the in situ $\mathrm{pH}$ of bacterial communities can consistently reduce their activity by $50 \%$ [32]. Moreover, the soil $\mathrm{pH}$ may impose a direct stress on bacterial cells at certain $\mathrm{pH}$ levels which may select for some bacterial taxa over others [33]. Consequently, a pattern that emerged with the apparent changes was the changes in relative abundance of the phyla Acidobacteria, Chloroflexi, Bacteroidetes, Actinobacteria, Firmicutes and Proteobacteria with soil $\mathrm{pH}$ across all the total landscapes (Fig. 1 and Table 3). Then, soil pH was a reasonable predictor of soil bacterial community composition in our study.

Soil $\mathrm{pH}$ also had an intimate correlation with other soil properties (for example, carbon availability) (Fig. S1) [32], yet the lack of clear data distinguishing the effects of consistent land-use on soil properties was most likely the result of variability in land-use changes across all the landscape [1]. Regardless of the causes, our results clearly indicated that SOC was also intimately correlated with the relative abundances of different dominant phyla and OTUs (negative and positive correlations) (Table 3 and Fig. 2b), which was consistent with previous studies showing that organic carbon availability limits microbial communities [34]. This is because labile organic material can rapidly alter bacterial communities by selecting for the populations that are most competitive in terms of growth rates and ability to absorb nutrients [34]. Thus, SOC could also be used as another predictor of bacterial richness and diversity (Fig. S2).

It was already known that plants might determine the quality and quantity of the litter substrate supply and modify the soil physical environment [35]. However, it is not yet clear which bacterial species are involved in the $\mathrm{N}, \mathrm{Ca}, \mathrm{Mg}$ and $\mathrm{P}$ cycling in our study, they were significantly correlated with dominant phyla and dominating OTUs. Nevertheless, we inferred that land-use changes might regulate soil bacterial communities by altering the soil carbon, nitrogen and phosphorus status and exchange ion mobility, as was reported by Shen et al. [33]. Moreover, Li et al. [36] have reported that crop residue can positively affect the activities of soil enzymes. So, bacteria with the ability to degrade cell wall compounds may exist in $\mathrm{E}, \mathrm{G}$ and $\mathrm{R}$ soils relevant to $\mathrm{C}$ soils, indicating an increase of bacterial guilds able to convert plant debris to nutrients/energy in undisturbed lands, grasslands or Eucalyptus forests.

da C Jesus et al. [37] recently reported that mostly Bacteroidetes were found in crop and pasture soils, Firmicutes were found in primary and old secondary forests, nearly half of the Actinobacteria were found in old secondary forests, Acidobacteria were more abundant in primary soils, and almost half of the Proteobacteria were found in crops. On a landscape scale, Sheik et al. [38] observed that Chloroflexi were more abundant in natural soils. By contrast, the relative abundance of Verrucomicrobia was highest in grasslands, although their ecology remains poorly understood [39]. Similar observations were found with other soils from tropical environments [39]. In this respect, the relative abundance of the dominate phyla depended on their living niches.

The bacterial community structures across our replicated karst soils differed among the different landuse types (Fig. 2), suggesting that changing land-uses disrupted the bacterial niches created by different types of vegetation [40]. Though Unweighted UniFrac uses an inferred evolutionary distance to measure similarity between samples, which is known to be unreliable, and Bray-Curtis methods are the more reliable choices [41], the Bray-Curtis and unweighted UniFrac results still revealed the similar dissimilarity between bacterial communities from four land-use types, suggesting that land-use determines the phylogenetic diversity of bacteria, as confirmed by ANOSIM tests in Fig. 4. The results were also consistent with those previously reported by Liao et al. [6] for land-use conversion from cropland to orchards in a degraded karst ecosystem. In this respect, our results suggest that soil bacterial communities differing dramatically among vegetation types across replicated karst lands with varying uses were linked to shifts in specific soil characteristics.

The PLS-PM model indicated that land-uses could influence bacterial community composition and alpha-diversity. However, it is worth noting that regardless of whether the influence on the bacterial community composition and alpha-diversity was positive or negative, the changes in land-use always led to an important decline in the bacterial biodiversity (Table 2), as has been previously reported by Tin et 
al. [40] in their results judging the consequences of changing biodiversity. Although the PLS-PM model alone cannot perfectly explain the influence on bacterial community composition, the response of karst soil bacterial communities to land-use type is still important for understanding how soil chemical properties shift the soil bacterial communities. Taken together, landuse type was found to be important in shaping bacterial communities.

\section{Conclusions}

The current research demonstrated the influence of karst land-use on soil bacterial communities. Although the dominant bacterial phyla across all of the soil samples were Acidobacteria, Proteobacteria, Chloroflexi, Actinobacteria, Firmicutes, Verrucomicrobia and Bacteroidetes, there were clear differences in soil bacterial community composition that were directly linked to the land-use in the given karst landscape. Moreover, according to the results from the PLS-PM model, we also found that land-use exerted a significant and direct influence on soil bacterial composition and their alpha diversity. Soil $\mathrm{pH}$ and SOC may be the important factors affecting the distribution of soil bacterial communities; however, we cannot determine which factor, $\mathrm{pH}$ or another soil characteristic, had the key influence on the relative abundance of different phyla and OTUs. Taken together, our findings demonstrate that karst soil bacterial communities change synchronously with land-use types, although more detailed analyses of the association between landuse changes and bacterial community should be done in the future.

\section{Acknowledgements}

This study was supported by the National Key Research and Development Program of China (No. 2016YFC0502501), the Special Funds for Local Science and Technology Development Guided by the Central Government, China (No. GuikeZY20198009), and the Fundamental Research Funds of Institute of Karst Geology (No. 2020022).

\section{Conflict of Interest}

The authors declare no competing interests.

\section{References}

1. JIANG Z., LIAN Y., QIN X. Rocky desertification in Southwest China: impacts, causes, and restoration. Earth-Sci Rev. 132, 1, 2014.

2. TONG X., BRANDT M., YUE Y., HORION S., WANG K., DE KEERSMAECKER W., TIAN F., SCHURGERS
G., XIAO X.M., LUO Y.Q., CHEN C., MYNENI R., SHI Z., CHEN H.S., FENSHOLT R. Increased vegetation growth and carbon stock in China karst via ecological engineering. Nature Sustainability. 1, 44, 2018.

3. SINGH K., SINGH B., SINGH R.R. Changes in physicochemical, microbial and enzymatic activities during restoration of degraded sodic land: Ecological suitability of mixed forest over monoculture plantation. Catena. 96, 57, 2012.

4. LAUBER C., RAMIREZ K., AANDERUD Z., LENNON J., FIERER N. Temporal variability in soil microbial communities across land-use types. ISME J. 7, 1641, 2013.

5. HE X.Y., WANG K.L., ZHANG W., CHEN Z.H., ZHU Y.G., CHEN H.S. Positive correlation between soil bacterial metabolic and plant species diversity and bacterial and fungal diversity in a vegetation succession on karst. Plant Soil. 307, 123, 2008.

6. LIAO H., ZHENG C., LI J., LONG J. Dynamics of soil microbial recovery from cropland to orchard along a 20 -year chronosequence in a degraded karst ecosystem. Sci Total Environ. 639, 1051, 2018.

7. FIERER N., JACKSON R.B. The diversity and biogeography of soil bacterial communities. P Nati Acad Sci. 103, 626, 2006.

8. JIANG M., LIN Y., CHAN T.O., YAO Y.J., ZHENG G., LUO S.Z., LIU D.P. Geologic factors leadingly drawing the macroecological pattern of rocky desertification in southwest China. Sci Rep. 10, 1440, 2020.

9. CHAUVAT M., PONGE J.F., WOLTERS V. Humus structure during a spruce forest rotation: quantitative changes and relationship to soil biota. Eur J Soil Sci. 58, $625,2007$.

10. QIU J., CAO J., LAN G., LIANG Y., WANG H., LI Q. The influence of land use patterns on soil bacterial community structure in the karst graben basin of Yunnan Province, China. Forests. 11, 51, 2020.

11. LI Q., PU J.B., HUANG N., DU H.M., QI X.K., WANG L., YANG H. A research approach for ecological, environmental and geological differentiation of rocky desertification and its driving mechanism in karst graben basin. Adv Earth Sci. 32, 899, 2017 [In Chinese with English abstract].

12. LI Q., HU Q., ZHANG C., MÜLLER W.E., SCHRÖDER H.C., LI Z., JIN Z. The effect of toxicity of heavy metals contained in tailing sands on the organic carbon metabolic activity of soil microorganisms from different land use types in the karst region. Environ Earth Sci. 74, 6747, 2015.

13. LI Q., HU Q., ZHANG C., JIN Z. Effects of Pb, Cd, $\mathrm{Zn}$, and $\mathrm{Cu}$ on soil enzyme activity and soil properties related to agricultural land-use practices in karst area contaminated by $\mathrm{Pb}-\mathrm{Zn}$ tailings. Pol J Environ Stud. 27, 2623, 2018.

14. MCKINLEY J.P., ZACHARA J.M., SMITH S.C., LIU C. Cation exchange reactions controlling desorption of ${ }^{90} \mathrm{Sr}^{2+}$ from coarse-grained contaminated sediments at the Hanford site, Washington. Geochim Cosmochim Ac. 71, 305, 2007.

15. DUQUESNE K., LIEUTAUD A., RATOUCHNIAK J., MULLER D., LETT M.C., BONNEFOY V. Arsenite oxidation by a chemoautotrophic moderately acidophilic Thiomonas sp.: from the strain isolation to the gene study. Environ Microbiol. 10, 228, 2008.

16. KUCZYNSKI J., STOMBAUGH J., WALTERS W.A., GONZÁLEZ A., CAPORASO J.G., KNIGHT R. Using QIIME to analyze 16S rRNA gene sequences from 
microbial communities. Curr Protoc Microbiol. 27, 1E.5.11E.5.20, 2012.

17. CALVET G., AGUIAR R.S., MELO A.S., SAMPAIO S.A., DE FILIPPIS I., FABRI A., TSCHOEKE D.A. Detection and sequencing of Zika virus from amniotic fluid of fetuses with microcephaly in Brazil: a case study. Lancet Infect Dis. 16, 653, 2016.

18. ÁVILA M.P., STAEHR P.A., BARBOSA F.A., CHARTONE-SOUZA E., NASCIMENTO A. Seasonality of freshwater bacterioplankton diversity in two tropical shallow lakes from the Brazilian Atlantic Forest. FEMS Microbiol Ecol. 93, fiw218, 2017.

19. VÁZQUEZ-BAEZA Y., PIRRUNG M., GONZALEZ A., KNIGHT R. EMPeror: a tool for visualizing highthroughput microbial community data. Gigascience. 2, 16, 2013.

20. CSARDI G., NEPUSZ T. The igraph software package for complex network research. InterJournal Complex Syst. 1695, 1, 2006.

21. BARBERÁN A., BATES S.T., CASAMAYOR E.O., FIERER N. Using network analysis to explore cooccurrence patterns in soil microbial communities. ISME J. 6, 343, 2012.

22. LANGILLE M.G., ZANEVELD J., CAPORASO J.G., MCDONALD D., KNIGHTS D., REYES J.A., BEIKO R.G. Predictive functional profiling of microbial communities using 16S rRNA marker gene sequences. Nat Biotechnol. 31, 814, 2013.

23. ROWLEY M.C., GRAND S., VERRECCHIA É.P. Calcium-mediated stabilisation of soil organic carbon. Biogeochemistry. 137, 27, 2018.

24. SANCHEZ G. PLS path modeling with R. Trowchez Editions, Berkeley, 2013.

25. ZUPANČIČ N., MILOŠ M., HELENA G. Geochemical fingerprint of insoluble material in soil on different limestone formations. Catena. 170, 10, 2018.

26. XU Z.W., JIANG Y., ZHANG Y.G., JIANG D.M. Soil exchangeable base cations along a chronosequence of Caragana microphylla plantation in a semi-arid sandy land, China. J Arid Land. 5, 42, 2013.

27. WANG W., DAI W. Study on soil $\mathrm{pH}$ and acidic buffering properties in Anhui Province. Chin Agric Sci Bull. 15, 17, 2012 [In Chinese with English abstract].

28. JIANG Y., WU Y., GROVES C., YUAN D., KAMBESIS P. Natural and anthropogenic factors affecting the groundwater quality in the Nandong karst underground river system in Yunan, China. J Contam Hydrol. 109, 49, 2009.

29. LI Q. Land-use types leading to distinct ecological patterns of soil bacterial and eukaryota communities in karst graben basin. Acta Geoscientica Sinica. DOI: 10.3975/ cagsb.2020.100701 [In Chinese with English abstract].

30. POWERS J.S., SALUTE S. Macro- and micronutrient effects on decomposition of leaf litter from two tropical tree species: inferences from a short-term laboratory incubation. Plant Soil. 346, 245, 2011.

31. FREEDMAN Z., ZAK D.R. Soil bacterial communities are shaped by temporal and environmental filtering: evidence from a long-term chronosequence. Environ Microbiol. 17, 3208, 2015

32. FERNÁNDEZ-CALVIÑO D., BÅÅTH E. Growth response of the bacterial community to $\mathrm{pH}$ in soils differing in pH. FEMS Microbial Ecol. 73, 149, 2010.

33. SHEN C., XIONG J., ZHANG H., FENG Y., LIN X., LI X., CHU H. Soil $\mathrm{pH}$ drives the spatial distribution of bacterial communities along elevation on Changbai Mountain. Soil Biol Biochem. 57, 204, 2013.

34. SAIFUDDIN M., BHATNAGAR J.M., SEGRÈ D., FINZI A.C. Microbial carbon use efficiency predicted from genome-scale metabolic models. Nat Commun. 10, 3568, 2019.

35. WALLENSTEIN M.D., MCMAHON S., SCHIMEL J. Bacterial and fungal community structure in Arctic tundra tussock and shrub soils. FEMS Microbial Ecol. 59, 428, 2007.

36. LI L., WILSON C.B., HE H., ZHANG X., SCHAEFFER S.M. Physical, biochemical, and microbial controls on amino sugar accumulation in soils under long-term cover cropping and no-tillage farming. Soil Biol. Biochem. 135, 369, 2019.

37. DA C JESUS E., MARSH T.L., TIEDJE J.M., DE S MOREIRA F.M. Changes in land use alter the structure of bacterial communities in Western Amazon soils. ISME J. 3, 1004, 2009.

38. SHEIK C.S., MITCHELL T.W., RIZVI F.Z., REHMAN Y., FAISAL M., HASNAIN S., KRUMHOLZ L.R. Exposure of soil microbial communities to chromium and arsenic alters their diversity and structure. PloS ONE. 7, e40059, 2012.

39. BERGMANN G.T., BATES S.T., EILERS K.G., LAUBER C.L., CAPORASO J.G., WALTERS W.A., FIERER N. The under-recognized dominance of Verrucomicrobia in soil bacterial communities. Soil Biol Biochem. 43, 1450, 2011.

40. TIN H.S., PALANIVELOO K., ANILIK J., VICKNESWARAN M., TASHIRO Y., VAIRAPPAN C. S., SAKAI K. Impact of land-use change on vertical soil bacterial communities in Sabah. Microb Ecol. 75, 459, 2018. 


\section{Supplementary Material}
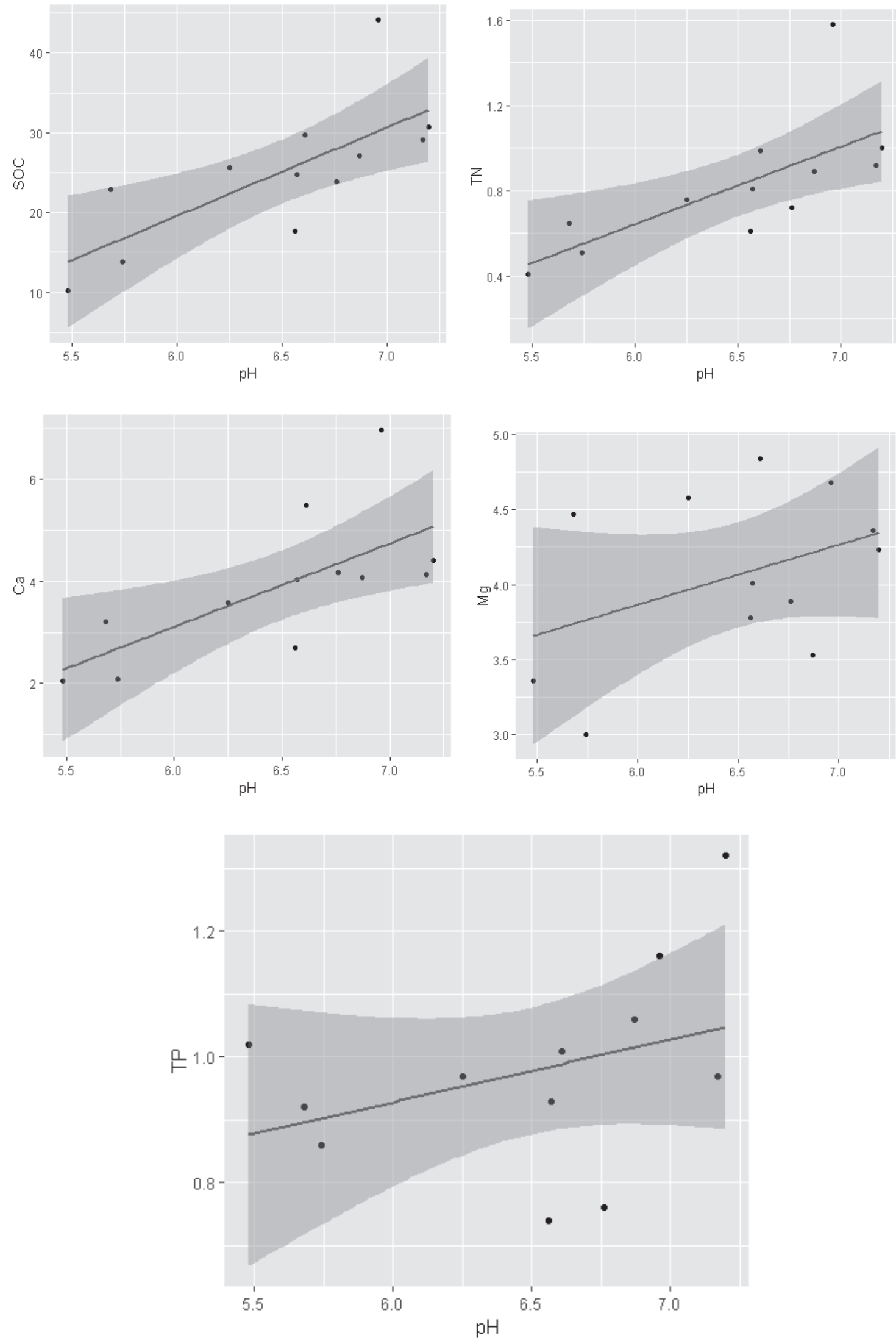

Fig. S1. The relationship between $\mathrm{pH}$ and other soil properties. 

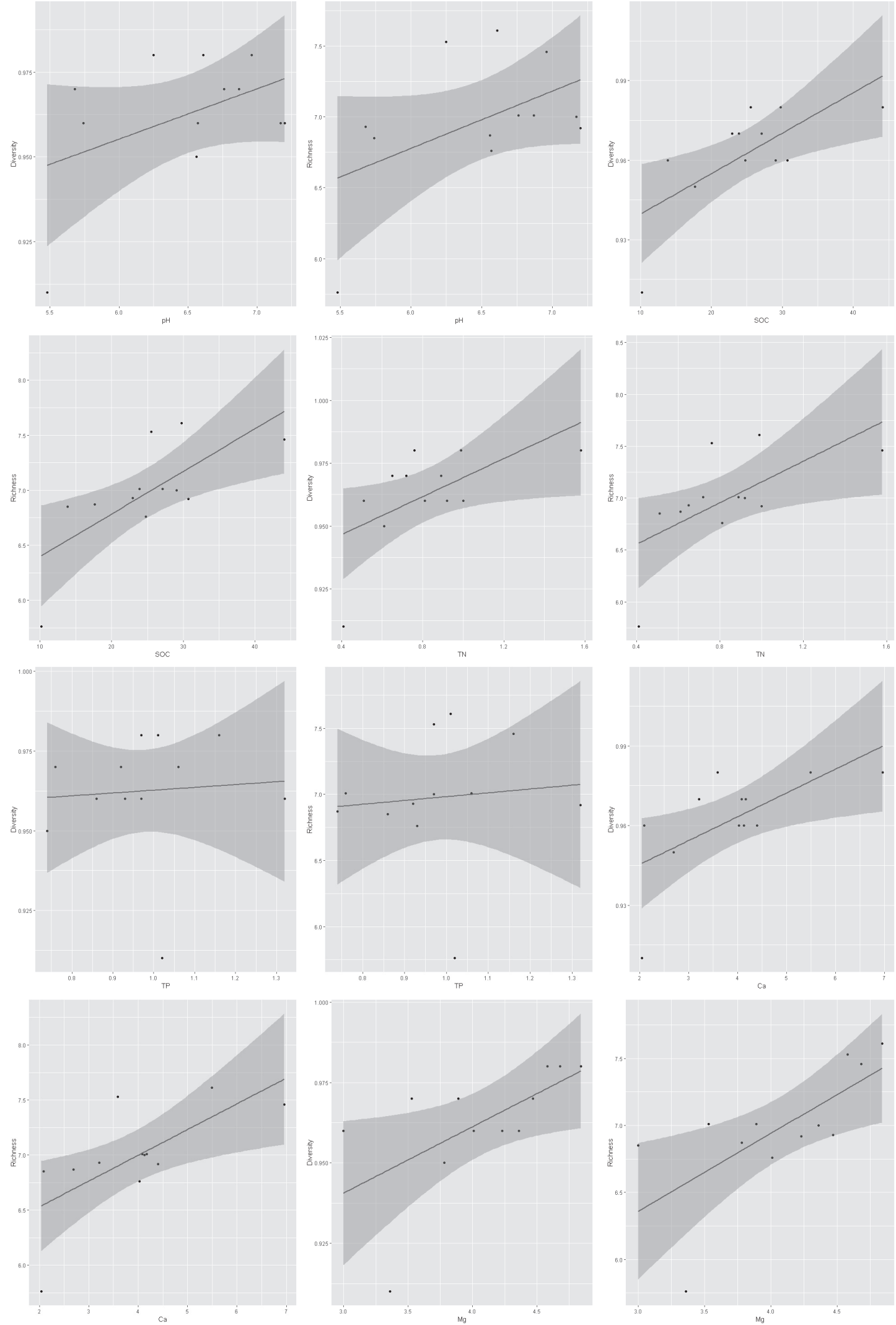

Fig. S2. The relationship between soil factors and bacterial diversity and richness.

Note: Diversity $=0.014 \mathrm{pH}+0.864, \mathrm{R}^{2}=0.211$; Richness $=0.403 \mathrm{pH}+4.357, \mathrm{R}^{2}=0.241$

Diversity $=0.001 \mathrm{SOC}+0.925, \mathrm{R}^{2}=0.434 ;$ Richness $=0.038 \mathrm{SOC}+6.011, \mathrm{R}^{2}=0.503$

Diversity $=0.034 \mathrm{TN}+0.932, \mathrm{R}^{2}=0.309 ;$ Richness $=1.001 \mathrm{TN}+6.154, \mathrm{R}^{2}=0.399$

Diversity $=-0.001 \mathrm{TP}+0.961, \mathrm{R}^{2}=0.00009 ;$ Richness $=0.264 \mathrm{TP}+6.718, \mathrm{R}^{2}=0.007$

Diversity $=0.008 \mathrm{Ca}+0.928, \mathrm{R}^{2}=0.364 ;$ Richness $=0.233 \mathrm{Ca}+6.063, \mathrm{R}^{2}=0.458$

Diversity $=0.019 \mathrm{Mg}+0.879, \mathrm{R}^{2}=0.362 ;$ Richness $=0.580 \mathrm{Mg}+4.618, \mathrm{R}^{2}=0.475$ 